\title{
Governance of mineral resources: Towards the end of national states' supremacy?
}

\section{The WTO and the case of rare earth elements as an illustrative example}

\section{Fanny Verrax}

Post-doctoral fellow, ENS Lyon (Frankrike), fanny.verrax@ens-lyon.fr

This paper addresses the issue of mineral resources' governance and trading rules. In doing so, it takes a closer look at the 2012 World Trade Organization (WTO) case pertaining to Chinese exportation quotas of rare earth elements and other minerals. It argues that the current governance system based on national responsibility over resources control and global trading rules is not well adapted to a sustainable and fair management of mineral resources, and concludes by suggesting two paths towards a better governance of such resources.

Keywords: WTO, rare earth elements, mineral resources governance

\section{Introduction}

The World Trade Organization (WTO) deals with the global rules of trade between nations. In the absence of a specific organization for natural resources, this entails manufactured goods, renewable natural resources like timber, and non-renewable resources, including fossil fuels and metal ores. The point of this paper is to argue that the trade of mineral resources in particular illustrates some deeper shortcomings of the WTO. Indeed, I will contend that the current rules of the WTO do not fit well the needs of the nations, on the exporting or importing side, and do not well enough enable environmental protection. Overall, the delicate rulings in cases involving mineral resources will be used as an argument against the permanence of national state as sole decision-maker and owner of mineral resources. Since this is a vast topic however, the discussion will be narrowed to a specific example: focusing on the case study of rare earth elements (REE).

The paper will start by providing some general context about the WTO, the Dispute Settlement Understanding (DSU) and how this tool has been used to deal with the trade of natural resources thus far. A more specific case study will then be introduced: the case(s) DS431-432-433, related to the exportation of rare earth elements, tungsten and molybdenum with China as a respondent. It will be shown how filing a case at the WTO is just one policy option among others available to the complainants and how complicated 
a ruling based on the GATT articles is. The following section will make sense of this case using two theoretical frameworks: the three narratives identified by Jost Wübbeke (2013) specifically about the WTO case and China's governance of its resources and the international society theory as developed by Martin Wight (1991). Finally, the paper will conclude that the national state governance system of mineral resources, which is at the core of the WTO's regulation, is an archaic and inefficient way of dealing with scarce, nonrenewable and unevenly distributed resources such as REE.

\section{Broader context on the WTO and trade in mineral resources}

When two or more countries disagree regarding any commodity's trade, they can settle this by resorting to the Dispute Settlement Understanding (DSU). The instauration of the DSU, agreed upon in the Marrakech Agreement (April 1994) was one of the main innovations of the WTO compared to the GATT (General Agreement on Tariffs and Trade). Described by many as the "jewel in the crown» of the Uruguay Round, the DSU allows members of the WTO to delegate the authority to settle disputes to a Dispute Settlement Panel. According to the WTO itself, «dispute settlement is the central pillar of the multilateral trading system, and the WTO's unique contribution to the stability of the global economy. Without a means of settling disputes, the rules-based system would be less effective because the rules could not be enforced» (WTO 2014b). Thus,

through the DSU, the WTO has acquired teeth; its rules can be enforced with an automaticity and with consequences that were quite alien to the GATT. These are major developments with systemwide consequences. (Narlikar, 2005: 85)

So, this tool allows countries to request consultations when another country is thought to be violating one of the trading rules of the WTO. Following the Chinese decision to reduce their export of rare earth elements, along with other minerals, the European Union decided to request consultations with China on March $13^{\text {th }} 2012$, followed shortly after by the United States and Japan (on March $22^{\text {nd }} 2012$ ). Among the WTO rules that are at stake here, are the articles VII, VIII, X and XI of the GATT 1994. These articles entail notably the fees and formalities connected with importation and exportation, as well as the general elimination of quantitative restrictions, both for importation and exportation. It is noteworthy that a similar case, DS394: «Measures Related to the Exportation of Various Raw Materials», was started in 2009, taking China to task on the same grounds. This case, also dealing with Chinese restrictions on raw materials exportation, led to a «recommendation to bring measures into conformity», on February $22^{\text {nd }} 2012$. The underlying rationale is that China's attempt to use Article XX (g) (exhaustion of nonrenewable resources and health protection) was not seen as relevant. It is likely that this ruling impacted the decision of the United States to file a new case, similar in many aspects, a couple of weeks later, hoping for a similar decision.

It was obviously not the first time the WTO ruled in a case involving natural resources. In fact, in 2010, the World Trade Report, an annual publication aiming to deepen under- 
standing of specific trade topics, was dedicated to "Trade and Natural Resources», to explain how these resources were considered within the WTO. It seems relevant to outline some of its main components here: the main features shared by all natural resources, and how the WTO has adapted its rules for their trade.

According to this report, natural resources, whether renewable or non-renewable, share five characteristics:

1 they are unevenly distributed;

2 they are exhaustible;

3 they may produce negative externalities;

4 they often represent a dominance in national economies;

5 their prices are highly volatile (WTO, 2010: 7-8).

In the case of rare earth elements, they can be said to comply with most of these general trends: exhaustibility, externalities and volatility. However, the uneven geographical distribution is actually less radical than typically assumed: China does extract more than 90 percent of rare earths elements (97 percent of the world production until very recently) yet possesses only one third to half of the world reserves, depending on references. Finally, its economy is not dependent on rare earth elements at all nor on the extractive industry in general, which accounts for less than 10 percent of its GDP (Wübbeke, 2013).

When it comes to the trade of natural resources, this has historically been a controversial issue almost since the very beginning of the WTO. Indeed, as early as 1958 the Haberler Report warned that the current trade policies were very biased and unfavorable to resources-rich, developing countries. This is obviously a very controversial topic, although it is usually widely accepted in economic theory that countries' specialization in one kind of production - be it natural resources or manufactured goods - is attributable to comparative cost advantage. When it comes to mineral resources however, many acknowledge the prevalence of the country's natural endowment, or, as put by Haberler:

The most obvious factors that explain a good deal of international trade are 'natural resources'land of different quality (including climate conditions), mineral deposits, etc. No sophisticated theory is required to explain why Kuwait exports oil, Bolivia tin, Brazil coffee and Portugal wine. (Haberler 1977: 4)

An economic theory becomes useful, however, in explaining why certain countries export minerals ores, when others process them domestically first, or even transform them into manufactured goods with a high added value. One can refer to the Staff Working Paper Trade in Mineral Resources (Davis 2009) for a thorough review of various economic theories addressing this issue. This report, which is a working staff paper from the WTO itself, is highly interesting in the sense that while it identifies and acknowledges many complexities and uncertainties linked to the topic of minerals extraction, processing and trade, it somehow chooses to disregard these and opt for a rather «linear model» in which the countries' endowments in mineral resources determine their trade patterns: 
All one can do given these complexities is to assume that a linear relationship between net exports and factor endowments is preserved even in the face of these violations of the model assumptions (...) This relationship may not be the relationship between factor input requirements, factor endowments, and trade flows recommended by the H-O-V theorem (...), but it would nevertheless be useful as a weakened hypothesis linking endowments to trade flows. (Davis 2009: 8)

The case of rare earth elements illustrates how flawed this «weakened hypothesis» can be: Indeed, China naturally does have a natural endowment of REE, but as seen before, it represents no more than half of the world reserve. So its almost perfect monopoly cannot be accounted for solely in terms of uneven distribution of geological ores; other aspects - notably environmental and political ones - are of paramount importance.

\section{The WTO case about REE}

The WTO case on export restrictions for REE and other materials highlights features that are common to all mineral resources but become even more critical when dealing with strategic materials. Indeed, even though the production of rare earth elements is minuscule (less than 95000 tons/year) its economic and strategic importance is of critical importance.

Rare earth elements (REE) are a group of seventeen metals including the family of lanthanides, scandium and yttrium ${ }^{1}$ with very similar chemical properties. These metals are of paramount importance for the development of new technologies, including hightech technologies (hard drives, flat panel displays for cell phones, TVs and laptops, audio systems, etc.) and green technologies (wind turbines and batteries for hybrid cars mostly). With about one third of the world reserves, China currently accounts for over 95 percent of world production. With worldwide demand increasing, over several years China has carried out a policy aimed at reducing exports, ${ }^{2}$ which several countries have reacted to, employing the Dispute Settlement Agreement of the World Trade Organization (WTO). Thus on March $13^{\text {th }} 2012$ the European Union requested «consultations with China with respect to China's restrictions on the export of various forms of rare earths, tungsten and molybdenum (WTO 2014a)». On March $22^{\text {nd }}$ 2012, Japan and the United States requested to join the consultation. The three complainants are therefore the United States (DS431), the European Union (DS432), and Japan (DS433), with China the defendant.

It is noteworthy to mention here that this case at the WTO was considered by the various stakeholders as one policy option among others in order to secure the supply chain in REE. In fact, an American report for the Congressional Research Service from June 2012 presents five different policy options regarding REE supply, challenging China on its export quotas at the WTO is among these. The other options are investing more in R\&D, authorizing and giving appropriate funding to the USGS (the «United States Geological Survey», for a comprehensive global assessment to identify economically exploitable REE deposits), supporting and encouraging greater exploration for REE, and establishing a stockpile (Humphries 2012). This document shows that the case at the WTO must be understood within a broader context in which the complainants are desperate to get 
access to this resource, and are hoping for a favorable ruling owing to a loophole in the general agreements of the WTO, and more specifically section XX.

China's defense is indeed predicated on the use of the General Exceptions of the GATT Agreement. More specifically, Article XX, «General Exceptions», Section (g) of the GATT Agreement stipulates that

nothing in this Agreement shall be construed to prevent the adoption or enforcement by any contracting party of measures (...) relating to the conservation of exhaustible natural resources if such measures are made effective in conjunction with restrictions on domestic production or consumption. (Gatt 1947)

It is worth pointing out that in DS394, China's attempt to use Article XX was not seen as relevant and China lost the case in the end. China's government still believes China to be in compliance with the WTO rules, as claimed by the Foreign Ministry spokesman Liu Weimin: «We think the policy is in line with WTO rules (...) Exports have been stable. China will continue to export, and will manage rare earths based on WTO rules.» (BBC World 2012)

There is no broad consensus among scholars regarding whether the WTO ultimately curbs or allows for environmental protection. Some argue that hyper liberalization and procedural features of the WTO - notably the fact that the burden of proof is placed on the shoulders of those arguing for environmental precaution - make environmental harm impossible to prevent (Conca 2000), while others claim that strict environmental national regulation is still possible within the WTO, and that «rather than demonizing the WTO, consumer and environmental advocates should concentrate on winning the debate for regulation at home» (Young 2005).

The ambiguity of article XX (g) was commented upon as early as in the 1990s. ${ }^{3}$ Among the elements that are not clear is the fact that «exhaustible» resource was not specific enough to know whether it was only non-renewable resources that were considered. Another problem, more relevant in our case, lies with the location of the pollution, usually considered to be within the importing country, without this being specified. Indeed, the majority of cases at the GATT/WTO involving environmental concerns usually happen the other way around: A country bans the import of a specific product, rather than export being reduced. A similar case though can be found in the dispute opposing USA and Canada in 1987 (GATT Panel Report, Canada - Measures Affecting Exports of Unprocessed Herring and Salmon, L/6268, adopted 22 March 1988, BISD 35S/98): Canada banned the export of unprocessed herring and salmon in order to protect the fisheries from over-exploitation. Although processed fish was allowed for export, this was with the proviso that it had been inspected in accordance with the Fish Inspection Act. The USA appealed to GATT on the grounds that the measure was designed to protect the Canadian processing industry, contravening Article XI which prohibits quantitative restrictions. Canada's defense was, in line with China and its quotas restrictions, the application of XX (g) to the effect that the measure was necessary for, and therefore related to, the conservation of its West Coast fisheries - even though it was not itself a direct conservation measure. The Panel ruled in favor of the USA and the restriction was found to 
contravene Article XI. It was inexcusable with recourse to XX (g) because the conservation was not the 'primary objective' of the scheme, which was the protection of employment:

While a trade measure did not have to be necessary or essential to the conservation of an exhaustible natural resource, it had to be primarily aimed at the conservation of an exhaustible natural resource to be considered as 'relating to' conservation within the meaning of Article XX (g). (Canadian Herring and Salmon case, Report of the Panel, BISD 35 S/98, at. 6.39)

Following that ruling, it therefore appears that China's use of article XX (g) is not relevant. "Most commentators accept that Canada's use of the environmental argument was an attempted disguise of protectionism which the Panel rightly exposed.» (Pearce 1992: 15)

An even more similar case is to be found in the already mentioned DS394, «Measures Related to the Export of Various Raw Materials», in which China had also contested exportations' restrictions in order to protect its natural resources. However, the panel concluded that:

China had argued in its defense that some of its export duties and quotas were justified because they related to the conservation of exhaustible natural resources for some of the raw materials. But China was not able to demonstrate that it imposed these restrictions in conjunction with restrictions on domestic production or consumption of the raw materials so as to conserve the raw materials. The Panel acknowledged, however, that China appears to be heading in the right direction in adopting a framework to justify its quotas under WTO rules, but that the framework is not yet WTO-consistent as it still has to be put into effect for domestic producers. (WTO 2013)

As for DS431, DS432 and DS433, the panel was formed on September $24^{\text {th }} 2012$, and at the time of writing (March $6^{\text {th }} 2014$ ), a decision has not yet been reached. No matter what the outcome of the case turns to be, it is important to understand the narratives behind China's resources policy and what it means in terms of resources management.

\section{Theoretical frameworks}

\section{Three narratives at work}

Wübbeke (2013) identifies three narratives at work in China's REE policy: the geopolitical narrative, the environmental narrative, and the development narrative. The geopolitical narrative focuses on control over natural resources, especially strategic materials, as a decisive factor prevailing in power struggles between countries. The paper shows that even though the public debate in China is sometimes framed according to this narrative, for instance when using the concept of baoweizhan, the «defense war», in which China must defend its resources against the West, it is the least prevailing narrative among Chinese politicians. More important narratives appear to be the environmental narrative and the development narrative. The environmental narrative entails a concern both for the conservation of a non-renewable resource and for the environmental impacts of the 
mining and processing industries. Supporting the first concern is a report issued by the Chinese Academy of Science on the conservation of resources, warning that China may exhaust its main ore in 35 years and become a «small power in rare earths». ${ }^{4}$ Finally, the development narrative focuses on the global and uneven division of labor and economic power relations between developed and developing countries. In this framework, imposing export quotas for strategic materials is a way to create and reinforce Chinese downstream industries, not to artificially raise the market prices of the commodity, as sometimes implied by Western commentators.

Altogether, it appears that the main two narratives at work in the Chinese policy choices for the governance of their natural capital do not fit well the Western-centered perception of a «Rare Earth War», according to which the Chinese quotas are mostly meant to win a power struggle between states. Beyond this dichotomy lies the question of how relevant the national scale is in dealing with the governance of natural resources.

\section{The international relations theory and the relevance of nation-states at stake}

Various political theories have studied power relationships between states. Among them, the international society theory has many supporters. This school of thought, also called liberal realism, predicates that there is a «society of states» at the international level, notwithstanding the condition of anarchy. Indeed, the so-called English School's triad ${ }^{5}$ distinguishes between three levels of responsibility that States people are confronted with, and which have been the focus of three different historical traditions:

1 Devotion to one's own nation and the well-being of its citizens (National Responsibility).

2 Respect for the legitimate interests and rights of other states and for international law (International Responsibility).

3 Respect for human rights (Humanitarian Responsibility).

Table 1: The three traditions in international relations theory

\begin{tabular}{|l|l|l|}
\hline $\begin{array}{l}\text { Scope of Statesmen's Respon- } \\
\text { sibility }\end{array}$ & $\begin{array}{l}\text { Martin Wight's three } \\
\text { traditions }\end{array}$ & $\begin{array}{l}\text { Main philosophers associ- } \\
\text { ated with the tradition }\end{array}$ \\
\hline National Responsibility & Realist & Machiavelli, Thomas Hobbes \\
\hline International Responsibility & Rationalist & Hugo Grotius, Emer de Vattel \\
\hline Humanitarian Responsibility & Revolutionist & Immanuel Kant \\
\hline
\end{tabular}

While realism and rationalism may need no further explanation, revolutionism may do so. Martin Wight describes revolutionists as «those who believe so passionately in the moral unity of the society of states or international society, that they identify themselves with it (...) they are cosmopolitan rather than 'internationalist', and their international 
theory and policy has 'a missionary character'» (Wight 1991: 8). The examples explored by Wight are the religious Revolutionists of the sixteenth and seventeenth centuries, the French Revolutionists, and the totalitarian Revolutionists of the twentieth century. Although this category can perfectly well be broadened to include those who nowadays support human rights and environmental protection as a moral standard above states' interests or agreements. Also, as emphasized by Wight, «the revolutionist tradition is less a stream than a series of waves. Here continuity is least important; there is rather a series of disconnected illustrations of the same politico-philosophical truths» (Wight 1991: 12). In this perspective, concern for environmental protection could then be seen as the latest avatar of the revolutionist «missionary character».

If we try to establish a parallel between the three previously identified narratives and this framework, we find that the geopolitical and the development narratives fit well with the realist tradition, as both have the well-being of the nation's people as their primary focus. As for the rationalist tradition, this would entail being concerned about conforming to international rules and agreements, such as the ones instituted by the WTO. As we have seen, however, not only is this not the main Chinese focus, but even the complainants filing the case at the WTO seem to use it more as a pretext. Finally, the environmental narrative may be understood as a humanitarian responsibility, albeit confined here to the national territory, both in terms of environmental impact of the mining activity and in terms of resource conservation.

This approach is rather problematic, and I contend that it touches upon a much deeper issue: How relevant is the national scale in dealing with environmental issues and, more specifically, with resource conservation? It is obvious that when the Chinese government decides not only to impose exportations quotas but also production quotas of REE, they try to preserve them as a national natural resource. Yet how does one make sense of such a notion in a globalized world in which international organizations, such as the WTO, have the right of inspection of national decisions, and in which every single country is, at least to some extent, resource-dependent?

According to the sociologist Martin Shaw, the whole international society theory must be understood in the context of the Cold War, yet it is no longer adapted to the world we live in:

The concept of international society has been put forward by its advocates as a 'central' position for international studies, a modal alternative to the extremes of brutish Hobbesian realism and utopian Kantian idealism. It incorporates the dominant realism of the subject, in its recognition of the dominance of independent sovereign states as actors in the international system; yet it makes a nod to idealism (as well as to social-scientific functionalism) in the role it assigns to consensus among actors as the basis for 'society'-like elements in the way this system develops. (...) The Cold War situation, in which the international state system contained the emergence of global society, is coming to an end. Groups, movements and institutions within global society are making themselves felt within the international states system which politically mediates global social relations. It is only right and proper that they should do so, even if it threatens the assumptions of the state system and challenges the norms of international society such as sovereignty and non-intervention. This is not to say that these norms are wholly redundant, but is to insist that they must be qualified by general accountability to the needs and wishes of the members of global society. (Shaw 1994: 69) 
My point here is that the resources conservation aspect of the Chinese policy, and other countries' attempts at resources control, is too often seen as a pretext for international power struggles, when the focus should shift to a more globalized vision of international resource scarcity, in which the nation state might not be the most relevant scale for its governance. Indeed, as rightly noted by $\mathrm{Hu}(2012)$, every state does regulate the natural resources it considers important, but this regulation goes beyond the national scope:

Although each State has sovereignty rights over natural resources within its jurisdiction, it is also in duty to utilize its resources for the benefits of its people as well as for the expansion of the world economy under international law. (Hu 2012: 658)

Although at first the author of this quote seems to broaden the nation's scope of responsibility, towards not only «its people» but «the world economy», it is interesting to note that the first statement is purely descriptive - «each State has sovereignty» - while the second one is normative and within the broader context of the paper sounds more like a wish the author formulates regarding Chinese political decision-makers: «Please study economics first and remember your duties towards the world economy.» Future generations are not mentioned here, although they should be included in the rights of «the people». Ultimately, the main pitfall: Is it really possible for a state to govern its natural resources for the benefit of its current and future people, as well as for the expansion of the world economy, while respecting international law? Given the current rules of the WTO, it does not seem so.

Indeed, the current rules do not allow for global production quotas of natural resources, while stating that exportation quotas are not compliant with the WTO. National states who take the initiative and institute national production quotas for their minerals obviously must couple this measure with an exportation quota, thus contravening to the WTO rules.

\section{Conclusion: Towards one world?}

To address this issue, I would like to suggest that a better governance of mineral resources would take one of the following paths: either a reform of the WTO allowing for national production quotas and therefore exportation quotas of natural resources, or a globalized governance of mineral resources instituting worldly quotas of mineral production, depending on various factors such as their scarcity in the Earth's crust, their recyclability and how much they can be a part of a circular economy, the environmental impact of the mining process and so forth. This option is not incompatible with free market, but it would end the madness of assuming that natural resources are infinite and should be governed using the same rules as services and manufactured goods (which in fact do consume a lot of natural resources). However, it seems to be a necessary shift as soon as we acknowledge living in «one world», as advocated by, among others, the consequentialist philosopher Peter Singer: 
How well we come through the era of globalization (perhaps whether we come through it at all) will depend on how we respond ethically to the idea that we live in one world. For the rich nations not to take a global ethical viewpoint has long been seriously morally wrong. Now it is also, in the long term, a danger to their security. (Singer 2004)

In any case, it is not by filing cases at the WTO and trying to use its loopholes, that countries will guarantee their security. Ultimately, a positive side effect of such a reform would be that the public distrust and feeling of uselessness regarding the WTO, as expressed in the massive protests of Seattle in 1999, would probably improve if the scope of action of the WTO was reduced and a specific organization was entrusted with the governance and trade rules of non-renewable resources.

\section{Noter}

${ }^{1}$ For a good introduction to rare earth elements, see Castor and Hedrick (2006).

${ }^{2}$ More specifically, in 2000 the Chinese government reduced export rebates for several commodities, including REE, and in 2005 trade of rare earth concentrate was banned. See Morrison and Tang (2012: 1516) and Tse (2011: 6).

${ }^{3}$ See Pearce (1992), to whom I borrow most of the ideas in the next section.

${ }^{4}$ Xu, G. \& Shi, C. (2005). Emergency call for the protection of the thorium and rare earth resources at Baiyun E'bo and the avoidance of radioactive pollution in the Yellow River and Baotou. Bulletin of the Chinese Academy of Sciences 20 (6), 448-450 [in Chinese]. Quoted by Wübbeke (2013: 391).

${ }^{5}$ The term was coined by Barry Buzan, based on Martin Wight's «three traditions». See Buzan (2004).

\section{References}

BBC World. (2012). US, EU and Japan challenge China on rare earths at WTO. Retrieved April $29^{\text {th }}$ 2014 from: http://www.bbc.co.uk/news/business-17348648

Buzan, B. (2004) From international to world society? English school theory and the social structure of globalisation. Cambridge: Cambridge University Press.

Castor, S.B. \& Hedrick, J.B. (2006). Rare earth elements. In Industrial minerals and rocks, eds. J.E. Kogel, N.C. Trivedi, J.M. Barker \& S.T. Krukowski, p. 769-792. Littleton, Colorado: Society for Mining, Metallurgy and Exploration.

Conca, Ken. (2000) The WTO and the undermining of global environmental governance. Review of International Political Economy, 7 (3), 484-494.

Davis, G.A. (2009) Trade in mineral resources. Staff Working Paper ESRD-2010-01. Retrieved March $6^{\text {th }} 2014$ from: http://www.wto.org/english/res_e/reser_e/ersd201001_e.pdf

GATT (1947). The general agreement on tariffs and trade (GATT 1947). Retrieved March $28^{\text {th }} 2014$ from: http://www.wto.org/english/docs_e/legal_e/gatt47_02_e.htm

GATT Panel Report, Canada - Measures Affecting Exports of Unprocessed Herring and Salmon, L/6268, adopted 22 March 1988, BISD (Basic Instruments and Selected Documents) 35S/98.

Haberler, G. (1977). Survey of circumstances affecting the location of production and international trade as analysed in the theoretical literature. In The international allocation of economic activity, eds. B. Ohlin, P.-O. Hesselborn \& P.M. Wijkman, p. 1-24. New York: Holmes \& Meier Publishers. 
$\mathrm{Hu}, \mathrm{D}$. (2012) China's governance of exhaustible natural resources under the WTO era: Taking its REE governance as a case. Energy Procedia, 16, Part A(0), 656-660. doi: http://dx.doi.org/ 10.1016/j.egypro.2012.01.106

Humphries, M. (2012). Rare Earth Elements: The Global Supply Chain. Congressional Research Service. CRS Report for Congress. Retrieved March $10^{\text {th }} 2014$ from http://www.relooney.info/ 0_New_14118.pdf

Morrison, W.M. \& Tang, R. (2012) China's rare earth industry and export regime: Economic and trade implications for the United States. CRS Report for Congress, Congressional Research Service. Retrieved April $29^{\text {th }} 2014$ from http://www.fas.org/sgp/crs/row/R42510.pdf

Narlikar, A. (2005) The World Trade Organization: A very short introduction. Oxford: Oxford University Press.

Pearce, D.W. (1992) Should the GATT be reformed for environmental reasons? CSERGE Working Paper GEC 92-06. Retrieved March $21^{\text {th }} 2014$ from http:// www.prototype2010.cserge.webapp3.uea.ac.uk/sites/default/files/gec_1992_06.pdf

Shaw, M. (1994). Global society and international relations: Sociological concepts and political perspectives. Cambridge: Polity.

Singer, P. (2004). One world: The ethics of globalisation. New Haven: Yale University Press.

Tse, P.-K. (2011) China's rare earth industry. Open File Report 2011-1042, U.S. Geological Survey.

Wight, M. (1991) International theory: The three traditions. Leicester and London: Leicester University Press.

WTO (2010) World trade report 2010: Trade in natural resources. Retrieved March $6^{\text {th }} 2014$ from: http://www.wto.org/english/res_e/booksp_e/anrep_e/world_trade_report10_e.pd

WTO (2013) Dispute settlement: Dispute DS394: China - Measures Related to the Exportation of Various Raw Materials. Retrieved March $28^{\text {th }} 2014$ from http://www.wto.org/english/tratop_ee dispu_e/cases_e/ds394_e.htm

WTO (2014a) Dispute settlement: Dispute DS432. China - Measures Related to the Exportation of Rare Earths, Tungsten and Molybdenum. Retrieved March $28^{\text {th }} 2014$ from http://www.wto.org/ english/tratop_e/dispu_e/cases_e/ds432_e.htm

WTO (2014b) Understanding the WTO: Settling disputes: A unique contribution. Retrieved March $28^{\text {th }} 2014$ from: http://www.wto.org/english/thewto_e/whatis_e/tif_e/disp1_e.ht

Wübbeke, J. (2013) Rare earth elements in China: Policies and narratives of reinventing an \begin{tabular}{|lllllll|}
\hline industry. Resources Policy, 38 & (3), 384-394. & doi: & http://dx.doi.org/10.1016/ \\
i.resourpol.2013.05.005 & & & & & & \\
\hline
\end{tabular}

$\mathrm{Xu}, \mathrm{J}$. (2011) Valeurs universelles ou valeurs chinoises? Le courant de pensée de l'historicisme dans la Chine contemporaine. Rue Descartes 72 (2), 52-68.

Young, A. R. (2005) Picking the wrong fight: Why attacks on the World Trade Organization pose the real threat to national environmental and public health protection. Global Environmental Politics 5 (4), 47-72. 